\title{
Między instynktem a racjonalnością - wartość najwyższa dla Nietzschego i Sokratesa
}

\author{
Maciej Wodziński \\ https://orcid.org/0000-0001-6347-5634
}

\begin{abstract}
Celem niniejszego artykułu jest polemika z przyjętym postrzeganiem kwestii uznawania wartości najwyższej przez Sokratesa oraz Fryderyka Nietzschego. Jednego przedstawia się zazwyczaj jako skrajnego racjonalistę, drugiemu przypisuje się natomiast wychwalanie witalności oraz postępowania instynktownego, którego celem miało być wzmaganie woli mocy. Przeprowadzona w artykule analiza wybranych wątków z pism Ksenofonta i Platona pokazuje, że myśli Ateńczyka nie można przypisać dogmatycznego intelektualizmu etycznego. Jego prawdziwymi celami okazują się: rozbudzanie niepewności swoich interlokutorów, zdobywanie nad nimi przewagi w dyskusji, co przyjmowało często formę słownego agonu, będącego odpowiednikiem woli mocy Nietzschego. Natomiast zestawienie postaci Kaliklesa z Platońskiego Gorgiasza z myślą Nietzschego pokazuje, że oprócz czystej instynktowności liczyła się dla nich również umiejętność jej opanowania i samo-przezwyciężenia. Konkluzją artykułu jest wykazanie, że zarówno Sokratesowi, jak i Nietzschemu nie należy przypisywać zwyczajowych, skrajnych stanowisk, a wartością uznawaną przez obu za najwyższą było posiadanie „instynktu racjonalności” - czyli takiego wykorzystania potencjału naszej plastycznej natury, które uzgodni wole mocy z rozumem.
\end{abstract}

Słowa kluczowe: Nietzsche, Sokrates, wartość najwyższa, aksjologia, wola mocy

MACIEJ WODZIŃSKI, student filozofii, Wydział Filozofii i Socjologii Uniwersytetu Marii CurieSkłodowskiej w Lublinie; adres do korespondencji: Instytut Filozofii UMCS, Pl. M. Curie-Skłodowskiej 4, 20-031 Lublin; e-mail: maciek.wodzinski@gmail.com 


\section{Zarzuty Nietzschego wobec racjonalizmu Sokratesa}

W swoich wczesnych Narodzinach tragedii analizując przyczyny upadku tradycyjnej formy tego gatunku sztuki, wywodzącej się z jednoczącego doświadczenia dionizyjskiego chóru, Nietzsche zauważa, że już u Sofoklesa widać zaczątki tego rozpadu. Jednak w pełni kryzys ten przejawił się dopiero w twórczości Eurypidesa, nacechowanej - zdaniem niemieckiego myśliciela - zbytnim dążeniem do „rozumienia”, zamiast do „odczuwania” fabuły tragedii. Wysunięcie na pierwszy plan tej potrzeby racjonalizacji i uczynienia spektaklu zrozumiałym dla przeciętnego widza przypisuje Nietzsche właśnie mistrzowi Platona, pisząc o Eurypidesie: „[...] bóstwem, które przezeń przemawiało, nie był Dionizos, nie był też Apollo, lecz zupełnie nowo narodzony demon imieniem Sokrates" ${ }^{1}$.

Ten pęd ku racjonalizmowi, podszyty optymistycznym założeniem, że nasza rzeczywistość może być do głębi zbadana i poznana za pomocą rozumu, zrodził dalsze zarzuty, czyniące z Sokratesa wyznawcę i poszukiwacza prawd dogmatycznych, wiecznych i niezmiennych ${ }^{2}$. Dążenie do całkowitego podporządkowania życia nakazom rozumu widział Nietzsche jako kastrację jego instynktowości i witalności, które to nakazy czyniły z życia pole męki i bitwy, wydanej przez człowieka własnym namiętnościom. Walka ta rodziła według niego w moralizatorach pokroju Sokratesa nieznośne poczucie resentymentu, które kazało im swym racjonalizmem sięgać poza siebie i zabijać zdrowe instynkty w innych ludziach, sprowadzając ich na drogę życia stłamszonego surowymi etycznymi regułami. Sytuacja ta, zdaniem Nietzschego, skutkowała zapoczątkowaniem i rozwojem choroby toczącej całą zachodnią kulturę już od czasów antycznych, czyli dekadentyzmử. Filozofia Platona, którego Sokrates miał zdaniem Nietzschego „zepsuć”, doprowadziła do ulokowania sfery najwyższych wartości poza sferą życia doczesnego.

\footnotetext{
${ }^{1}$ Friedrich Wilhelm Nietzsche, Narodziny Tragedii albo Grecy i pesymizm, tłum. Bogdan Baran (Kraków: Inter Esse, 1994), 96.

${ }^{2}$ Sokrates jest według Nietzschego winien ubóstwienia rozumu, jako narzędzia mogącego naprawić deficyty świata, winien powstania „zarozumiałej” nauki, w rozumieniu, jakie temu pojęciu przypisujemy dziś. Por. Drew Hyland, „Nietzsche’s »Love« for Socrates”, Humanities 4, nr 1 (2015): 3-16, DOI: 10.3390/h4010003; Walter Kaufman, „Nietzsche's admiration for Socrates”, Journal of the History of Ideas 9 , $\mathrm{nr} 4$ (1948): 472-491, DOI: 10.2307/2707219.

${ }^{3}$ Por. Friedrich Wilhelm Nietzsche, Zmierzch bożyszcz, tłum. Paweł Pieniążek (Kraków: Wydawnictwo Zielona Sowa, 2006), 15.
} 
Tę „alienację” wykorzystało później chrześcijaństwo, doprowadzając do wyjałowienia naszego, materialnego świata z poczucia jego wartościowości, której ludzie zaczęli szukać w transcendentnym wobec niego Bogu. Wraz z utratą poczucia sprawczej twórczości, słabła w nich też wola mocy; ludzie przestali wybierać to, co dla nich dobre, a skierowali się w stronę tego, co moralne. Porzucili instynkty, a na ich miejsce przyjęli kodeksy postępowania, co w konsekwencji doprowadziło do zupełnego upadku człowieka nowoczesnego ${ }^{4}$.

Zarzuty Nietzschego brzmią poważnie, lecz trzeba spojrzeć na nie krytycznym okiem. To, co nazywa on „niszczącą siłą rozumu”, w rzeczywistości, w odpowiednich rękach, może okazać się czymś zupełnie innym: zmuszaniem siebie i innych do ciągłego namysłu nad własnymi granicami oraz do ich przekraczania.

Warto zacząć od uwagi, że w oczach Nietzschego ideałem mędrca był sceptyk $^{5}$ : „Potęgi, wolności, płynącej z siły i nadsiły ducha, dowodzi się sceptycyzmem. Ludzie przekonani nie wchodzą w ogóle pod uwagę, gdy rozpatruje się wszelkie zasadnicze problemy wartości i nie wartości"6. A zatem jakakolwiek wiara $\mathrm{w}$ istnienie obiektywnej prawdy jest dla Nietzschego nie do przyjęcia. Za wyraz takiej potępianej wiary uznaje również filozofię Platona, która mimo iż była jego zdaniem dostojna (w przeciwieństwie do plebejskiej myśli Sokratesa), to była również dogmatyczna ${ }^{7}$.

Niemiecki filozof akceptuje przyjęcie pewnych przekonań jedynie jako chwilowego środka do osiągnięcia celu. Człowiek prawdziwy, mocny, autentycznie myślący nie może sobie pozwolić na zniewalającą i pozbawiającą ruchu myśli wiarę. Musi nieustannie pytać, drążyć, kwestionować, torować sobie drogę do „prawdy”. Musi być sceptykiem, aby w tym dążeniu poruszać się ciągle naprzód

${ }^{4}$ Tamże, 73-75.

${ }^{5}$ Por. Friedrich Wilhelm Nietzsche, Antychrześcijanin, tłum. Grzegorz Sowinski (Kraków: ZW Nomos, 1996), 97: „Wielkie duchy są sceptykami. Zaratustra jest sceptykiem”.

6 Tamże, 97.

${ }^{7}$ Por. Friedrich Wilhelm Nietzsche, Wola mocy, tłum. Stefan Frycz, Konrad Drzewiecki (Kraków: Wydawnictwo Zielona Sowa, 2003), 168: „Co w filozofie jest zacofane? To, że swoje jakości głosi on jako konieczne i jedyne jakości, wiodące do osiągnięcia »najwyższego dobra« (np. dialektykę, jak Platon). Że wszystkim gatunkom człowieka każe wznosić się gradatim do swego typu jako najwyższego. Że lekceważy to, co skądinąd wysoko jest cenione - że otwiera przepaść między najwyższymi kapłańskimi a świeckimi wartościami. Że wie, co jest prawdą, co jest Bogiem, co jest celem, co jest drogą ... Typowy filozof jest tutaj absolutnym dogmatykiem; jeśli potrzeba mu sceptycyzmu, to jeno dlatego, żeby o $s w o j e j$ rzeczy głównej mógł mówić dogmatycznie”. 
i nie dać się usidlić w jednym przytulnym przekonaniu, że prawdę odnalazł. Człowiek autentyczny wykorzystuje przekonania jako środek do celu, dogmatyczna wiara zaś jest „potrzebą słabości”, jest wołaniem o protektorat do jakiejś wyższej instancji, która zdjąć by mogła z jego barków brzemię odpowiedzialności, będącej ceną za autentyczność. Wiara jest dla Nietzschego wyzbyciem się siebie samego, własnego myślenia, jest niewolnictwem w kajdanach „bez-myślności”. Autor Antychrześcijanina zauważa też: „Istnieją pytania, w przypadku których decyzja o prawdzie i nieprawdzie nie jest rzeczą człowieka; wszystkie naczelne pytania, wszystkie naczelne problemy wartości leżą poza sferą ludzkiego rozumu... Pojmowanie granic rozumu - to dopiero jest naprawdę filozofia"8.

Wydaje się, że - jak zostanie pokazane - Sokrates był niezwykle blisko tak pojmowanego ideału nietzscheańskiego „wielkiego ducha”, szukając odpowiedzi na „naczelne pytania” i badając rozległą przestrzeń pomiędzy czystą racjonalnością, o którą był oskarżany a czystym instynktem, którego wbrew pozorom Nietzsche również nie akceptował.

\section{Sokrates - racjonalność za wszelką cenę?}

Jaki mógł być zatem cel Sokratejskiej metody, jeżeli nie było nim dążenie do odkrycia jedynej prawdy? Na to pytanie otrzymamy rozliczne i bardzo różniące się od siebie odpowiedzi. Ważnym, choć często marginalizowanym świadectwem na ten temat mogą być już słowa Arystotelesa. W Metafizyce Stagiryta pisze między innymi tak: „Sokrates natomiast interesując się naturą świata jako całości, zajmował się zagadnieniami etycznymi, poszukując wśród nich pojęć ogólnych, i po raz pierwszy skierował uwagę na definicje” ${ }^{10}$ oraz „Sokrates jednak nie przyznawał oddzielnego istnienia ani ogółom, ani definicjom. Dopiero jego następcy przyznali im oddzielne istnienie i nazwali je Ideami”"11.

Nawet jeśli trudno pogodzić się z tak „okrojonym” obrazem Sokratesa, sprowadzającym go do roli badacza języka i logiki, to wspólnym punktem przekazów

\footnotetext{
${ }^{8}$ Nietzsche, Antychrześcijanin, 99.

${ }^{9}$ Tamże, $97-100$.

${ }^{10}$ Arystoteles, Metafizyka, tłum. Kazimierz Leśniak (Warszawa: Wydawnictwo Naukowe PWN, 1984), 987b.

${ }^{11}$ Tamże, 1078b.
} 
Arystotelesa wydaje się wskazywanie na Platona, jako na twórcę teorii Idei. Sokratesowi zaś, podobnie jak Cyceron, przypisuje „sprowadzenie filozofii na ziemię”, której istotę dopiero jego najwybitniejszy uczeń wyniósł z powrotem do nowego, inteligibilnego świata ponadzmysłowego. Twierdzenia te mogą zostać wsparte karykaturalnym przekazem Arystofanesa, który ukazywał syna Sofroniskosa raczej jako obrotnego sofistę niż poszukiwacza wiecznej i obiektywnej prawdy na temat natury dobra czy sprawiedliwości. Przyjęcie takiej interpretacji obu starożytnych przekazów jest o tyle istotne, że pomaga zdjąć z barków Sokratesa oskarżenia o dogmatyczność i monopolizowanie wiedzy na temat tego, co faktycznie jest dobre, co jest sprawiedliwe, czy co jest pobożne.

Podobnego zdania jest również Guthrie, pisząc: „Nawet Ksenofont, który zgodnie ze swoim temperamentem i apologetycznym celem, ukazuje nam Sokratesa znacznie bardziej konstruktywnego, dużo częściej przedstawia go rozważającego i badającego (skopon) z przyjaciółmi naturę tej lub innej cnoty niż pozytywnie stwierdzającego, czym ona jest"12.

Aby podkreślić ten aspekt Sokratesowej nauki zwróćmy też uwagę na kilka konkluzji z wybranych dialogów autorstwa Platona i Ksenofonta oraz opinii ich komentatorów ${ }^{13}$.

Po dość długiej i krętej dialektycznej dyskusji Ksenofontowy Eutydem mówi: „Wybacz, drogi Sokratesie, ale ja już tracę wiarę w sens swoich odpowiedzi. To wszystko, co poprzednio mówiłem, wydaje mi się teraz całkiem inne, niż sądziłem przed chwilą [pogrub. M.W.]"14.

Właśnie ten moment „utracenia wiary” we własne przekonania, wybicia z intelektualnej stagnacji jest podstawowym celem Sokratesowych zabiegów. Rzeczy i sprawy początkowo czarno-białe, okazują się mienić całym spektrum barw, okazują się być grą światło-cieni, w których nigdy do końca nie możemy być pewni,

${ }^{12}$ William Keith Chambers Guthrie, Sokrates, tłum. Krzysztof Łapiński, Sławomir Żuławski (Warszawa: Aletheia, 2000), 150.

${ }^{13}$ Autor artykułu jest świadomy skali skomplikowania problemu, jaki stanowi tzw. „kwestia sokratyczna" oraz związanych z nią wątpliwości, co do jakości i różnej wagi poszczególnych świadectw na temat Sokratesa. Niemniej jednak, podążając w tej kwestii za opinią uznanych badaczy tego problemu, takich jak Guthrie czy Dies, przyjmuje podejście komparatystyczne, nieodrzucające żadnego z przekazów, a mające na celu takie wykorzystanie każdego z nich, które pozwoli na wyeksponowanie jego znaczenia dla konkretnie omawianej kwestii i linii interpretacyjnej. Por. Guthrie, Sokrates, 13.

${ }^{14}$ Ksenofont, „Wspomnienia o Sokratesie”, w: Ksenofont, Pisma Sokratyczne, tłum. Leon Joachimowicz (Warszawa: Wydawnictwo Naukowe PWN, 1967), IV, 2, 19. 
co jest prawdą, a co nie. Lecz ten, z pozoru wyłącznie negatywny, efekt, jest jedynie „efektem ubocznym” procesu dialogicznego, ponieważ owo wzruszenie fundamentów naszej pewności, nie ma doprowadzić do tego, abyśmy „załamali ręce” i stracili wiarę w możliwość każdego rodzaju wiedzy i pewności. Zabiegi Sokratesa, mają nam pokazać, żebyśmy nie okopywali się na jednych i niezmiennych pozycjach „wiary”, ale żebyśmy testowali wszelkie przekonania, które w naszych oczach aspirują do miana wiedzy pewnej.

Mądrości nie utożsamia zatem Sokrates z wiedzą w rozumieniu prawdy ostatecznej, którą objawić możemy innym. Mądrością jest natomiast: nie przestawać badać i zmniejszać własnej ignorancji, szukać własnych słabości i przez to zbliżać się do majaczącej gdzieś na horyzoncie Prawdy ${ }^{15}$. Podstawowym celem Sokratesa było więc przekraczanie, transgresowanie samego siebie i swoich ograniczeń, zarówno intelektualnych, jak i praktyczno-moralnych oraz wskazywanie tej drogi, a nie celu innym ${ }^{16}$. Podobny pogląd na znaczenie postaci Sokratesa ma Kierkegaard, uznając go raczej za pobudkę i podnietę do rodzenia myśli, a nie za ich dostarczyciela ${ }^{17}$ : „Sokratejski ruch jest zmierzaniem ku temu co dobre. Jego znaczenie w dziejach powszechnych polega właśnie na zmierzaniu (a nie dojściu). Jego znaczenie dla współczesności sprowadza się do wskazania innym kierunku drogi. Nie oznacza to, że doszedł do celu pod koniec życia, albowiem sens jego życia to: nieustanie iść i pozwolić iść innym"18.

Kolejnym przykładem, w którym ten niedogmatyczny aspekt myśli Sokratejskiej został wyeksponowany jest Platoński Eutyfron. Syn Fainarety, mówiąc kolokwialnie, „udaje głupka” i prosi lokalnego wieszczka, mającego się za autorytet w dziedzinie pobożności, o nauczenie go, czym ta forma cnoty w istocie jest. W toku dyskusji, którą animuje mistrz Platona, skonstruowanych zostaje dziewięć definicji pobożności, które jedna po drugiej są przez Sokratesa obalane i odrzucane. Po przejściu całej tej „drogi”, podczas której Eutyfronowi nie udało się powiedzieć nic, co można by zaakceptować jako definicję pobożności, wieszczek ucieka, aby uwolnić się od kolejnych niewygodnych rozważań, a Sokrates (i my

\footnotetext{
${ }^{15}$ Por. m.in. Reginald Hackforth, „Great thinkers. (I) Socrates”, Philosophy 8, nr 31 (1933): 265, DOI: $10.1017 /$ S0031819100032939

${ }^{16}$ Por. też Ksenofont, „Wspomnienia o Sokratesie”, I 1,16; IV 6,1; III 9,9.

${ }^{17}$ Por. Soren Kierkegaard, Okruchy filozoficzne, tłum. Karol Toeplitz (Warszawa: Wydawnictwo Naukowe PWN, 1988), 8-13.

${ }^{18}$ Soren Kierkegaard, O pojęciu ironii z nieustającym odniesieniem do Sokratesa, tłum. Alina Djakowska (Warszawa: Wydawnictwo KR, 1999), 230.
} 
razem z nim) nie uzyskuje odpowiedzi na kardynalne w tym dialogu pytanie: „Jak ty rozumiesz zbożność i bezbożność, i w sprawie zabójstwa, i w innych?”19. A jednak, mimo braku jednoznacznej odpowiedzi, Sokrates wychodzi ze „starcia” mądrzejszy o całą tę drogę, która rozwiała wiele z dotychczasowych mniemań i pokazała, że nie powinno się tak pochopnie rozważać poważnych spraw.

Co ważne, właśnie w tym samym duchu w mowie O starych i nowych tablicach przemawia Nietzscheański Zaratustra, który powiada do swoich uczniów: „O bracia moi! Gdzież jest największe niebezpieczeństwo dla wszelkiej ludzkiej przyszłości? Nie znajdujeż się ono pośród dobrych i sprawiedliwych? - jako tych co mawiają i w sercach swych czują: »my wiemy, co zacz dobre jest i sprawiedliwe, mamy to wszak już; biada tym, którzy tu jeszcze szukają« [...]. Dobrzy bowiem tworzyć nie mogą: oni są zawsze początkiem końca"20.

Czy zatem faktycznie mamy tu do czynienia $\mathrm{z}$ dogmatykiem, czy może jednak ze sceptycznym mędrcem, nieufnym wobec zastanych i skostniałych pojęć kultury, chcącym popychać naprzód, niczym Zaratustra, wybranych uczniów nie $\mathrm{w}$ nowo nadanym przez siebie kierunku, ale w ich własnym? ${ }^{21}$.

Dodatkowym potwierdzeniem tej tezy mogą być również słowa Arystotelesa, który w $O$ dowodach sofistycznych stwierdza, że: „Sokrates nie bronił swoich tez, lecz tylko pytał, chciał bowiem w ten sposób wyznać, że odpowiedzi nie zna"22.

Odnosząc się jeszcze krótko do Nietzscheańskich zarzutów dotyczących Sokratesowego moralizatorstwa, należy koniecznie zwrócić uwagę na kwestię intelektualizmu etycznego, który, zakładał, że wyłącznie wiedza jest gwarantem słusznego postępowania, a ktoś, kto ją posiada, nigdy nie będzie $\mathrm{z}$ własnej woli czynił źle. Bezwarunkowe przyjęcie takiego stanowiska, któremu Sokrates wielokrotnie daje wyraz, byłoby faktycznie mocnym potwierdzeniem zarzutów Nietzschego, zgodnie z którymi rozum i umiejętność zdobywania informacji przejmowały cał-

${ }^{19}$ Platon, „Eutyfron”, w: Dialogi, t. I, tłum. Władysław Witwicki (Kęty: Antyk, 1999), 5c.

${ }^{20}$ Friedrich Wilhelm Nietzsche, Tako rzecze Zaratustra, tłum. Wacław Berent (Gdynia: Wydawnictwo Tenet, 1991), 250.

${ }^{21}$ Por. również na temat niekonkluzywności dialogów Sokratejskich: Ryszard Legutko, Sokrates, filozofia męża sprawiedliwego (Poznań: Zysk i S-ka, 2013), 636-640 oraz Dariusz Olesiński, „Elenktyka jako therapeia w świetle Platońskiego Eutyfrona”, w: Therapeia, askesis, mediatio, red. Krzysztof Łapiński, Robert Pawlik, Rafał Tichy (Warszawa: Wydawnictwo UW, 2017), 49-60.

${ }^{22}$ Arystoteles, „O dowodach sofistycznych”, w: Arystoteles, Dzieła wszystkie, t. I, tłum. Kazimierz Leśniak (Warszawa: Wydawnictwo Naukowe PWN, 1990), 183b 6-8. 
kowitą kontrolę nad postępowaniem człowieka. Jednak w relacji Ksenofonta, kwestia ta nabiera nieco innego wydźwięku. Broniąc przyjaciela przed zarzutem, jakoby to Sokrates winien był zepsucia Alkibiadesa i Kritiasza, poświęca więcej uwagi powyższej kwestii, pisząc między innymi: „Widzę przecież, że podobnie jak ci, którzy nie ćwiczą ciała, nie mogą podejmować trudów fizycznych, tak samo ci, którzy nie ćwiczą duszy, nie mogą sprostać trudom duchowym. [...] Moim zdaniem każda szlachetna zaleta wymaga ciągłego ćwiczenia, a już najbardziej cnota umiarkowania"23.

Zatem według Ksenofonta, który wiernie starał się przestrzegać nauk przyjaciela, nawet Sokrates dopuszczał możliwość „zejścia na złą drogę” przez człowieka prawego. Wydaje się nawet, że przyjęcie takiej ewentualności jest niezbędne, jeżeli filozofię traktować będziemy poważnie, jako duchowe ćwiczenie w rozwoju moralnym i intelektualnym. Jak zauważa syn Gryllosa, czym innym jest cnotę zdobyć, a czym innym jeszcze ją utrzymać. To pierwsze jest dostrzegalnym, dość dobrze określonym punktem na horyzoncie działania, jednak najtrudniejszą częścią zadania jest, gdy już ten szczyt osiągniemy, umieć się na nim utrzymać. A to nie zawsze udawało się nawet samemu Sokratesowi. Jednak w tym właśnie leży sens duchowego ćwiczenia, jakim jest filozofia, aby umieć po upadku się podnieść i aby na nowo eksplorować obszary, przed którymi dawno już postawiono tablicę z zakazem wstępu.

Gdy podczas opisanej przez Ksenofonta uczty Charmides pyta Sokratesao, dlaczego swoim uczniom nakazuje panowanie nad namiętnościami, sam zaś został przez niego przyłapany na zalotach do Kritobulosa ${ }^{24}$, ten wcale nie wypiera się swojej „chwili słabości”, potwierdzając zdarzenie i mówiąc, że spotkała go za to zasłużona kara w postaci bólu ramienia - „jakby mnie jakaś dzika bestia ugryzła"25. Opisana sytuacja nasunąć może zatem dwa ciekawe wnioski. Po pierwsze - i to gładko wpisywałoby się w linię „złagodzonego" intelektualizmu etycznego przedstawioną przez Ksenofonta - nawet ten najcnotliwszy z mędrców miewał chwile słabości, czasem dawał się opanować mani2 ${ }^{26}$ i mógł popełnić błąd. Ważne,

\footnotetext{
${ }^{23}$ Ksenofont, „Wspomnienia o Sokratesie”, I 2, 19-23.

${ }^{24}$ Ksenofont, „Uczta”, w: Ksenofont, Pisma Sokratyczne, tłum. Leon Joachimowicz (Warszawa: Wydawnictwo Naukowe PWN, 1967), 4, 27.

${ }^{25}$ Tenże, „Uczta,” 4,29.

${ }^{26}$ Por. Ksenofont, „Wspomnienia o Sokratesie”, III, 9,6; Dorota Tymura, Sokrates Ksenofonta (Lublin: Wydawnictwo UMCS, 2017), 161: „Twierdził, że szaleństwo jest przeciwieństwem mądrości,
} 
że później umiał się opamiętać i trzeźwiej osądzać sytuację. Druga ewentualność, posiadająca nawet dalej idące implikacje, ujawnia się, gdy przypomnimy sobie rozmowy Sokratesa z Alkibiadesem i słynną Teodotą. Mistrz Platona potrafił doskonale zapanować nad sobą w obecności inteligentnego, szlachetnie urodzonego i uchodzącego za jednego najprzystojniejszych Ateńczyków, nawet gdy ten próbował aktywnie zdobyć jego względy. Potrafił też nad sobą zapanować, będąc $\mathrm{w}$ towarzystwie uwodzicielskiej hetery, w dodatku tak manipulując relacją, aby i tu doprowadzić do odwrócenia ról, samemu ze zwierzyny stając się łowcą. Skoro tak, to dlaczego nie potrafił utrzymać w ryzach swojego pożądania przy Kritobulosie? A może właśnie, i hipoteza ta doskonale pasuje do projektowanego tu obrazu, Sokrates w tamtej akurat chwili wcale nie miał zamiaru tego robić?

Twierdzenie o zupełnej niemożliwości wybrania zła zamiast dobra przez osobę posiadającą odpowiednią wiedzę, które często w relacji Platona powtarza jego mistrz, zdaje się czymś wręcz nieludzkim, a na pewno niezgodnym z naszym potocznym doświadczeniem. Może być więc ono sprytnym, retorycznym wybiegiem, stosowanym w dyskusjach, aby rozmowę właściwie ukierunkować (tak jak miało to miejsce w przypadku rozmowy z Protagorasem czy Gorgiaszem), bądź pewnym sztucznym dodatkiem samego Platona, wynikającym z przygotowywania gruntu pod wprowadzenie teorii Idei. Jeżeli taka koncepcja powoli już się w jego umyśle wykluwała podczas pisania wczesnych dialogów, bardzo możliwe, że już wtedy potraktował Platon pojęcia takie jak Prawda czy Dobro absolutystycznie. A skoro takie byty istniały, to istnieć musiała też odpowiadająca im wiedza, którą zdobyć należało. Któż zatem byłby bardziej godzien jej posiadania, jeżeli nie sam Sokrates?

W taki oto sposób, wkładając w jego usta zbyt wiele swoich słów, Platon mógł poniekąd Sokratesowi zaszkodzić, dając doskonałe argumenty jego antagonistom, upatrującym w Sokratesie zatwardziałego racjonalisty i moralisty. Zarysowanie tej „linii demarkacyjnej” pomiędzy Sokratesem historycznym (jeżeli o takim w ogóle można mówić) a Platońskim, wydaje się ważnym punktem wyjścia dla dalszych analiz prowadzonych $\mathrm{w}$ tym artykule.

Podsumowując dotychczasowe rozważania, należy wskazać, że Sokrates nie koncentrował się na wyznaczaniu etycznych standardów, na oświecaniu uczniów gotową Wiedzą i Prawdą. Głównym przesłaniem jego myśli i działań było bowiem

jednak nie utożsamiał ignorancji z szaleństwem. Nieznajomość samego siebie oraz mniemanie i przekonanie, że wie się to, czego się nie wie uważał za stan najbliższy szaleństwu”. 
wytrącanie siebie i otoczenia z psychicznej „strefy komfortu”. Mistrz Platona doskonale zdawał sobie sprawę z wagi swojego zadania. Wiedział, że przytłaczający ciężar tradycji wraz z promowanym przez sofistów ideałem absolutnie relatywnej wiedzy i prawdy zbierają swoje żniwo w postaci dotkliwych dla Aten konsekwencji. Ten moralny upadek współobywateli, drażnił go nie tylko ze względu na nieszczerość i chaos, jaki wprowadzał w życie społeczeństwa, ale również dlatego, że prowadził do degeneracji wartości dla Sokratesa niezwykle istotnej - samodzielnego i niezgnuśniałego myślenia, które było warunkiem koniecznym - choć niewystarczającym - dobrego i autentycznego życia - wartości najwyższej zarówno dla niego, jak i dla Nietzschego. Analiza tego, co oznaczało owo „dobre życie”, będzie przedmiotem dalszej części artykułu.

\section{Nietzsche i Kalikles - witalność i moc za wszelką cenę?}

Dialogiem, któremu warto poświęcić w kontekście niniejszych rozważań nieco więcej uwagi jest Platoński Gorgiasz. Jest on ważny z trzech powodów. Po pierwsze, poprzez kontrast pomiędzy zawartymi w nim tezami a tymi głoszonymi przez Sokratesa w Protagorasie (są ze sobą dosłownie sprzeczne) uzmysławia czytelnikowi moc Sokratejskiej ironii. Sokrates nie utrzymuje już w Gorgiaszu, że cnoty nie da się nikogo nauczyć, a dobro jest tym samym, co przyjemność. Pokazuje to, że maski, za jakimi skrywać się umie mistrz Platona, stają się, w zależności od potrzeby: narzędziem w procesie samopoznania rozmówcy lub ostrzem wymierzonym w oponenta, które pozwala ujawnić jego ignorancję lub fałsz. Drugim powodem jest kolejne podkreślenie niekonkluzywności dialogów, których bohaterem jest mistrz Platona, a więc braku jednoznacznych i autorytatywnych odpowiedzi na zadawane pytania. Po trzecie zaś, dialog ten ukazuje bodaj najtrudniejsze starcie Sokratesa z niezwykle „nietzscheańskim” politykiem, jakim jest Kalikles $^{27}$. Starcie, z którego bardzo trudno będzie wyjść Sokratesowi obronną ręką

\footnotetext{
${ }^{27}$ Por. m.in.: Milena Fisher, „Nietzsche o moralności”, w: Nietzsche i tradycja antyczna, red. Bogdan Banasiak, Paweł Pieniążek (Toruń: Wydawnictwo Adam Marszałek, 2012), 221-231; Dariusz Konrad Sikorski, „Sofistyka, nihilizm, totalitaryzm - myśli na XXI wiek”, Słupskie Prace Filologiczne. Seria Filologia Polska 2004, nr 3: 223-234; Gilles Deleuze, Nietzsche i filozofia, tłum. Bogdan Banasiak (Warszawa: Wydawnictwo Spacja, 1993), 64; Stanisław Letkiewicz, Moralność dla wszystkich czy dla każdego? (Katowice: Wydawnictwo Uniwersytetu Śląskiego, 2011), 50.
} 
bez „ucieczki w zaświaty”, a którego inne rozwiązanie, bazujące po części na dotychczasowych ustaleniach, postaram się zaproponować.

Akcja dialogu rozpoczyna się po retorycznym popisie Gorgiasza, który zawitał do Aten. Z początku w dyskusji z Sokratesem biorą udział sam Gorgiasz oraz jego uczeń Polos. Obaj jednak szybko dają się uwikłać swojemu rozmówcy w sprzeczności i aby zachować twarz przed zgromadzoną publicznością, kończą uczestnictwo w dyspucie. Jednak, gdy milkną sofiści, oto na scenie pojawia się najtrudniejszy z przeciwników, wytrawny polityk - Kalikles, w którym dostrzega się nierzadko pierwowzór Nietzscheańskiego nadczłowieka (lub dopiero jego wychowawcy).

Będąc doświadczonym uczestnikiem życia politycznego Aten, Kalikles dobrze zna realia funkcjonowania i prawa rządzące w tej demokratycznej polis. Nie ma złudzeń co do tego, że panujący ustrój jest daleki od doskonałości, podatny na zewnętrzne wpływy i korupcję, a jednocześnie w dużej mierze zależny od decyzji motłochu, którego rozwaga, inteligencja i cnotliwość pozostawiały raczej wiele do życzenia. Zatem w opinii na temat swoich rodaków nie różni się tak bardzo od Sokratesa, równie trafnie diagnozując chorobę toczącą jego miasto-państwo. Patrząc na system „od środka”, Kalikles dokładnie zna zagrożenia, jakie wiążą się z panującą sytuacją ogólnego zepsucia i braku krytycznego myślenia u znaczącej części społeczeństwa, która umożliwiała łatwe manipulowanie tłumem, na czym zyskiwali sofiści. Jednak w przeciwieństwie do Sokratesa, w tym chaosie polityk widzi szansę (tak jak i sofiści) uzyskania znacznych wpływów, podniesienia swojej pozycji społecznej. Bezwzględnie ją wykorzystuje, ale w odróżnieniu od Gorgiasza i Polosa (próbujących zachować fasady „nauczycieli cnoty”), wcale nie wstydzi się do tego przyznać. Mówiąc krótko: Kalikles to typ rasowego polityka, który nierozerwalnie wiązać się musi z każdym systemem demokratycznym - choć może bardziej szczery niż większość podobnych mu działaczy.

Już na samym początku swojej mowy Kalikles, będący zdecydowanym zwolennikiem prawa natury, a nie prawa stanowionego (zwłaszcza w sposób demokratyczny), ujawnia swój pogląd na tę kwestię, który staje się preludium do rozwinięcia szerszych widoków na przyszłość Aten: „Ja mam wrażenie, że ci, co prawa układają, to są ludzie słabi, to ci, których jest wielu. Oni dla siebie, dla swojej własnej korzyści ustanawiają prawa, ustalają pochwały, formułują nagany, bo się boją żwawszych jednostek spośród ludzi, takich, którzy by potrafili więcej mieć niż oni 
- boją się, żeby ci nie posiedli więcej od nich, więc mówią, że brzydką i niesprawiedliwą rzeczą jest wyprzedzać drugich własnym majątkiem i że jest krzywdzeniem drugich: starać się posiadać więcej niż oni”28. A zaraz później podaje receptę na lek, który pomoże uzdrowić sytuację w państwie, receptę brzmiącą dziwnie znajomo dla każdego, komu nie jest obcy koncept Nietzscheańskiego nadczłowieka: „Ale, jeśli się trafi mąż z odpowiednią naturą, to wszystko to strząśnie z siebie, przełamie, wyrwie się i podepce nasze formułki i kuglarskie sztuczki, i łagodne uroki świętych słów, i prawa przeciwne naturze wszystkie; powstanie i ukaże się jako pan nasz; on, niewolnik; wtedy rozbłyśnie sprawiedliwość natury”29.

Widząc z jakim przeciwnikiem będzie miał do czynienia, Sokrates cieszy się, że jego przekonania zostaną wystawione na najcięższą próbę i traktuje to spotkanie, jako swego rodzaju kamień probierczy dla własnej duszy i przekonań. Stając naprzeciw człowieka, dla którego moc, siła witalna, umiejętność radzenia sobie w życiu i zdobywania coraz większych korzyści stanowią wartości najwyższe, mistrz Platona wie, że dzieli ich zbyt wielka przepaść, aby można zbudować nad nią most $\mathrm{z}$ racjonalnych argumentów. Mimo to podejmuje dialektyczną próbę i faktycznie, udaje mu się kilkukrotnie zapędzić rozmówcę w kozi róg. Jednak ten, w przeciwieństwie do swoich poprzedników, nie ma najmniejszego problemu z odwoływaniem swoich poprzednich twierdzeń, ani z przyznaniem, że owszem, logika dialektycznego wywodu podpowiada jedno, i tu Sokrates ma rację, ale praktyka życia politycznego i osiągane korzyści przeważają szalę na stronę rozwiązań nieetycznych ${ }^{30}$.

Platon, pisząc Gorgiasza, najwyraźniej zdawał sobie sprawę z tej trudności i tym razem to on, a nie jego przeciwnik, zmuszony był coś w tej dyskusji poświęcić, żeby nie przyznać się do przewagi Kaliklesa. Jego argumentów nie może zbić dialektycznymi sztuczkami, ponieważ nie kryją się one za zasłoną dbałości o cnotę czy dzielność, jak u sofistów. Są przedstawione wprost i nie ma tu czego dialektycznie obalać, bo żadna wykazana logiczna sprzeczność nie może swoją mocą przebić argumentu Kaliklesa, który głosi, że by przetrwać w tym brutalnym świecie, kierować się trzeba prawem natury.

Myśl Platona obciążona jest jedną zasadniczą cechą, która w starciu z „nietzscheańskim” Kaliklesem okazuje się kotwicą, ciągnącą go w dół: triadą Dobra,

\footnotetext{
${ }^{28}$ Platon, „Gorgiasz”, w: Dialogi, t. I, tłum. Władysław Witwicki (Kęty: Antyk, 1999), 483 b-c.

${ }^{29}$ Tamże, 484a.

${ }^{30}$ Por. tamże, $482 c-482 e$.
} 
Piękna i Prawdy jako bytami samoistnymi, najpełniejszymi, najwyższymi oraz inteligibilnymi. Dla Platona niezależnie od sytuacji panującej w świecie doczesnym, w ostatecznym rozrachunku partykularne interesy jednostek, cały kurz, brud, okrucieństwo i głupota tego świata nie mogą zyskać przewagi nad Prawdą samą i Dobrem samym. Nie może być też mowy o oscylowaniu między nimi, transie, jakiego nauczał Sokrates. One zatriumfować muszą, nawet jeśli już nie w tym świecie. Właśnie dlatego, dla ostatecznego zwycięstwa i udowodnienia swojej moralnej przewagi, Platon musi na ołtarzu Idei poświęcić samego Sokratesa oraz to, co zdaje się sednem jego troski, czyli trans autentycznej myśli życia doczesnego. Musi odwrócić się od życia tu-i-teraz, aby utrzymać istnienie najwyższej Prawdy. Dlatego ucieka w mit o zaświatach, w którym dobre uczynki zawsze zostają odpowiednio wynagrodzone, a złe ukarane.

Ta część dialogu, staje się właściwie monologiem, który ma doprowadzić do udowodnienia wyższości stanowiska Sokratesa (Platona). Opowiada on mit o pośmiertnym sądzie, na którym stawić się muszą dusze zmarłych i tam, stojąc nago przed sędziami, zostaną ocenione wedle swego postępowania $\mathrm{w}$ świecie doczesnym i skierowane na Wyspy Szczęśliwe - w przypadku tych, co ku Dobru się kierowali lub do Hadesu - odbywać wieczną karę z Tantalem czy Syzyfem i im podobnymi, których dusze całe były pokryte bliznami zbrodni i krzywoprzysięstwa $^{31}$. Jednak nie było to zwycięstwo Platona, a raczej kapitulacja. Platon doskonale widział i nawet otworzył furtkę do innego rozwiązania sporu pomiędzy Kaliklesowym instynktem i Sokratejską racjonalnością. Otworzył, lecz przez nią nie przeszedł, ponieważ nie prowadziła w stronę bezwarunkowego zwycięstwa jednej ze stron, a jedynie otwierała przestrzeń „pomiędzy” tymi dwiema skrajnościami przestrzeń Sokratesa. Właśnie z powodu tego rozróżnienia istotne było wprowadzenie wcześniej dość wyraźnej granicy, pomiędzy Sokratesem samym a Sokratesem Platona. Jakkolwiek jest to rozwiązanie narażone na wiele możliwych zarzutów, to jednak pozwala na zbliżenie do siebie poglądów dwóch - pozornie antagonistycznych - tytułowych myślicieli.

Owa możliwość „innego rozwiązania” sporu z Kaliklesem pojawia się we fragmentach 491e-492a, gdy stwierdza on: „To wielcy durnie, Sokratesie; bo jak może być szczęśliwy człowiek, który jest niewolnikiem czyimkolwiek. Nigdy; tylko to jest piękne i sprawiedliwe z natury, co ja ci teraz otwarcie mówię, że człowiek,

\footnotetext{
${ }^{31}$ Tamże, 522e-527e.
} 
który ma żyć jak należy, powinien żądzom swoim puścić wodze, niechaj będą jak największe, i nie powściągać ich. A kiedy będą jak największe, wystarczą wtedy

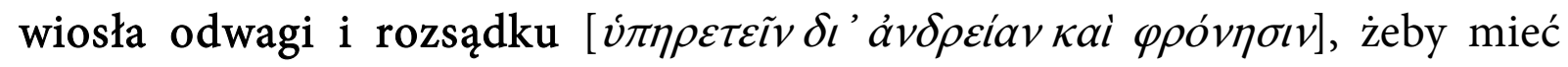
pełno, po brzegi, wszystkiego, ku czemu się żądza kiedykolwiek ruszy [pogrub. M.W.]".

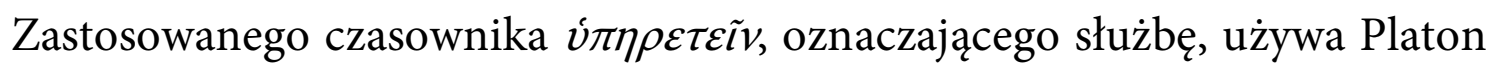
również w Eutydemie (281d), tłumacząc, że pewne dobra służą nam zdecydowa-

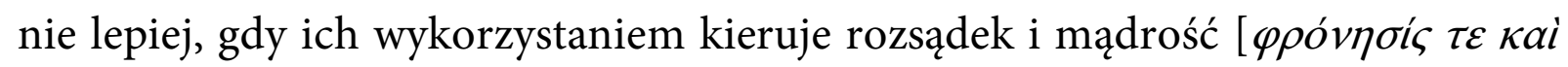

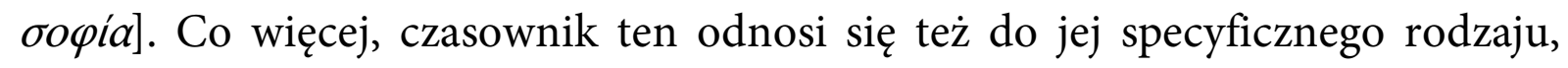
a mianowicie do służby na pokładzie statku, aby być jeszcze bardziej precyzyjnym: w charakterze wioślarza. Platon być może więc celowo odsyła nas do swojej znanej (choć wyrażonej explicite dopiero w późniejszym Fedonie) metafory: drugiego żeglowania. Określenie to bowiem (deuteros plous), stosowane było do nazwania sytuacji, w której statek nie mógł poruszać się z powodu braku wiatru, w związku z czym wybierano najlepszą dostępną metodę wprawienia go w ruch i sięgano po wiosła, które nie dość, że pozwalały okręt napędzać, to dodatkowo ułatwiały znacząco manewrowanie nim, a więc i sterowanie, czyniąc podróż bezpieczniejszą.

Inne, anglojęzyczne tłumaczenia cytowanego wyżej fragmentu Gorgiasza, zamiast poetyckich „wioseł odwagi i rozsądku” Witwickiego, podają tu na przykład: „manly energy and wisdom” (Cope) czy „courage and intelligence” (Jowett) - akcentując jednak aspekt wykorzystania tych zdolności w służbie żądzom. Niemniej jednak warto zwrócić uwagę, że zaspokajaniu ich, według Kaliklesa, służyć mają (podobnie jak w przypadku Eutyfrona): ả $v \rho \rho \varepsilon i ́ \alpha v-$ męstwo, odwaga oraz, co ważniejsze, $\varphi \rho o ́ v \eta \sigma \iota v$ - rozum, rozsądek, mądrość. Jednak przywołanie w tym właśnie miejscu metafory wioślarskiej, zwłaszcza dość ściśle powiązanej z wykorzystaniem rozsądku, sugeruje wyraźnie, iż owa „służba” żądzom, polega również na rozumnym znalezieniu odpowiedniego sposobu kierowania nimi.

Dlatego właśnie tak istotny okazuje się komentarz polskiego tłumacza do tego punktu, zgodny, co do zasady, z zamysłem autora niniejszego artykułu (i poglądem Nietzschego na kwestię woli mocy, zwłaszcza w odczytaniu Heideggera), rzucający nowe światło na kwestię współgrania (a nie wykluczania się) u Kaliklesa „rozbudzonych żądz” oraz „rozsądku”: „Jednakże instynkt, jeżeli ma być twórczy, musi być ujęty w karby. Jeżeli życie ludzi w społeczeństwach nie ma być cichą 
wojną wszystkich przeciwko wszystkim, muszą jednostki ludzkie posiadać zdolność do powstrzymywania własnego życiowego pędu tam, gdzie im to zdrowy rozsądek albo instynkt społeczny dyktuje. Ta zdolność - to panowanie nad sobą"32.

Z początku może wydawać się to wniosek zbyt daleko idący, zwłaszcza, że chwilę wcześniej Kalikles dość wyraźnie dał do zrozumienia, że wyklucza panowanie nad sobą samym, jako instancję zagrażającą realizacji wszelkich możliwych pragnień jednostki wybitnej. Jednak chwilę później Witwicki w swoim komentarzu znów trafia w sedno, niwelując, zdawałoby się, niemożliwe do pogodzenia różnice, pomiędzy rozmówcami dialogu: „Jednakże i Kalikles wymaga pewnej pracy nad sobą. Określa ją jako służbę wioślarską około żądz, którą ma w człowieku pełnić odwaga i rozsądek. Zdawałoby się, że istnieje przepaść między nim a Sokratesem, u którego rozsądek czy rozum ma nie: służyć żądzom wiosłem, ale: stać nad nimi u steru. Różnica może nie wyda się nam tak wielką, jeżeli, odrzuciwszy alegorie, zważymy, że i sokratesowy ideał człowieka nie może i nie powinien być wolny od wszelkich żądz i że obaj dyskutujący jednakowo wymagają od człowieka, by o kierunku jego działania, o postanowieniach jego nie decydowały same bezpośrednie pobudki uczuciowe, tylko, obok nich, pobudki pośrednie, dalsze, myśli o skutkach oddalonych, refleksje, jakie przypisujemy pospolicie rozsądkowi. Różnica między nimi tkwi nie tyle w zasadach, ile w upodobaniach i w niechęciach"33.

Nawet więc bezwzględnie pragmatyczny polityk zdaje sobie sprawę z tego, że podążając jedynie za przyjemnością i żądzą władzy, a więc żywiołem witalności i woli mocy, stać się może tym, czego tak nienawidził - niewolnikiem. Niewolnikiem własnych namiętności, które zaburzają niejednokrotnie trzeźwy osąd sytuacji. A kto chce odnieść sukces w walce o władzę i wpływy, nie może sobie na taki błąd pozwolić. Niestety, Platon, choć widział tę możliwość, nie zdecydował się na pełniejszą jej eksplorację i wykorzystanie, poświęcając ją (razem z Sokratesem) w imię rozwiązania „zaświatowego” i - jego zdaniem - ostatecznego.

Właśnie tej bezwładności w pogoni za poczuciem mocy, musi zapobiegać tak promowany przez Sokratesa rozum (rozsądek). Moc - tak, ale nie za wszelką cenę $^{34}$. Ponieważ liczy się nie tyle samo jej wykorzystywanie, co zachowanie chęci

${ }^{32}$ Tamże, 404, przypis 51.

${ }^{33}$ Tamże, 405, przypis 52.

${ }^{34}$ Warto zwrócić uwagę na słowa Heideggera, które dobrze oddają założone tu pojmowanie woli mocy: „Właśnie wtedy, gdy myślimy podstawowe słowa »wola« $\mathrm{i}$ »moc« w pewnym sensie słownikowo poprawnie w duchu Nietzschego, grozi największe niebezpieczeństwo, że całkowicie strywializujemy 
jej zdobywania i ruchu, który nam to umożliwia. To jest właśnie sedno „woli mocy", którą posiadał również Sokrates, a którą w podobny sposób interpretował na przykład Heidegger. Według niego, Nietzsche pojmował wolę mocy jako „rozkaz”, odczucie „posiadania przewagi i to nie tylko nad innym, tym, który słucha, ale także i przede wszystkim przewagi nad samym sobą. To oznacza: przewyższenie, wzięcie własnej istoty górą, jednak w taki sposób, że własna istota ostaje się w tym przewyższeniu" 35 .

Jak widać, tak Kalikles, jak i sam Nietzsche, zdawali sobie sprawę, że zupełne poddawanie się popędom i pożądaniom, nie prowadzi do niczego dobrego. Należy zatem rozbudzać swoją ambicję, należy dążyć do mocy i panowania nad innymi, ale nie w sposób bezmyślny i bezrozumny, który prowadziłby do braku panowania nad sobą samym i ulegania każdej możliwej żądzy. Owe „wiosła odwagi i rozsądku”, są tym, co łączy Nietzschego i Kaliklesa z Sokratesem. Wszyscy trzej doskonale wiedzieli, że funkcjonują w przestrzeni „pomiędzy” instynktem a racjonalnością, w przestrzeni trans-aksjologicznej, i wiedzieli, że każde zaspokajanie potrzeb musi być połączone z rozumną ich analizą oraz analizą środków, jakie do celu prowadzą.

Autor Zaratustry nie chciał tak naprawdę unicestwienia rozumu, a jego odrodzenia, ponieważ każde zaburzenia w tym zakresie są już wynikiem upadku i degeneracji państwa jako całości. Upadku, o który obwiniał on Sokratesa, a spowodowanego między innymi następującą po nim plagą moralizatorstwa i wynoszenia kwestii etycznych do rangi wartości najwyższych ${ }^{36}$. Tej czystej potrzebie panowania i okiełznania również własnych instynktów Nietzsche daje wyraz na przykład w Woli mocyi Zmierzchu bożyszcz, odcinając się jednocześnie od płytkich, hedonistycznych interpretacji jego koncepcji, pisząc: „Nie zaspakajanie woli jest przyczyną przyjemności (przeciw tej powierzchownej teorii walczę szczególniej - bezmyślne to fałszowanie psychologiczne rzeczy najbliższych), lecz iż wola dąży naprzód i wciąż staje się panią tego, co spotyka na swej drodze. Uczucie

ideę woli mocy, tzn. utożsamimy ze sobą wolę i moc; uznamy wolę za moc i moc za wolę. W ten sposób nie ujawni się to, co rozstrzygające w słowach »Wille zur Macht", wola mocy, a mianowicie owo - »ku « (zu). [...] Dalekowzroczną mocą, której władanie spełnia się w budującym, selektywnym i unicestwiającym myśleniu, jest »wola mocy «", w: Martin Heidegger, Nietzsche, t. I, tłum. Andrzej Gniazdowski i in. (Warszawa: Wydawnictwo Naukowe PWN, 1998), 640-641.

${ }^{35}$ Tamże, 641-642.

${ }^{36}$ Por. Nietzsche, Zmierzch bożyszcz, 34. 
przyjemności kryje się właśnie w niezaspakajaniu woli, w tym że bez przeciwnika i oporu nie czuje się dość syta [pogrub. M.W.]” ${ }^{37}$; „Wszystkie namiętności mają swój okres, gdy są jedynie zgubne, gdy całym ciężarem głupoty ściągają swoje ofiary w dół [...] Ten sam środek, przycinanie, tępienie, w walce z żądzą wybierają instynktownie ci, którzy mają zbyt słabą wolę, którzy są zbyt zdegenerowani, by w swej żądzy móc narzucić sobie miarę, owe natury potrzebują [...] jakiejś ostatecznej deklaracji wrogości, jakiejś przepaści między sobą a namiętnością [pogrub. M.W.]"38.

Jak widać w tych dwóch fragmentach, nawet Nietzsche dostrzega zagrożenie w niekontrolowanym zaspokajaniu żądz i namiętności, widzi potrzebę kontroli nad nimi, a prawdziwym dostarczycielem przyjemności jest według niego uczucie mocy wynikające $\mathrm{z}$ ciągłego przekraczania własnych ograniczeń. Tę możliwość kontroli i opanowania się uznaje wręcz za niezbędną w życiu nadczłowieka, ponieważ tylko wola niezaspokojona ciągle szuka nowych wyzwań i możliwości udowodnienia sobie samej własnej mocy sprawczej i zdolności kontroli ${ }^{39}$. Dla Kaliklesa doskonały przywódca polis, dla Nietzschego wprowadzający ludzkość w nową erę nadczłowiek, a dla Sokratesa każdy z nas, powinien cechować się ambicją, duszą namiętną i pożądliwą, ale też zdolną do rozumnego kierowania tymi namiętnościami. Co więcej, w drugim z powyższych fragmentów widzimy też, czego Nietzsche w postawie moralistów nie akceptował. Nie chodziło mu bowiem o opanowywanie własnych namiętności, bo to, jak zobaczyliśmy, była dla niego ważna zaleta, ale o ich kompletne usuwanie, pozbywanie się ich i unikanie konfrontacji z nimi naszej woli i naszej mocy.

${ }^{37}$ Tenże, Wola mocy, 221.

${ }^{38}$ Tenże, Zmierzch bożyszcz, 27-28.

${ }^{39}$ Warto zwrócić tutaj uwagę na rzucające się w oczy podobieństwo tej charakterystyki do opisu charakteru Sokratesa, jaki znaleźć możemy w jego psychobiografii stworzonej przez Witwickiego (por. Platon, „Uczta”, 12-13). Ten fragment wstępu tłumacza do Ucztyjest dokumentem o tyle szczególnym, że stanowi pierwszą na świecie, wydaną w 1909 roku (drugą wydaną rok później była psychobiografia Leonarda da Vinci autorstwa Freuda) rekonstrukcję portretu psychologicznego postaci historycznej na podstawie dostępnych świadectw dotyczących twórczości czy faktów z życia (por. Jacek Leoński, „Historia wykorzystywania dokumentów osobistych w socjologii", Ruch prawniczy, ekonomiczny i socjologiczny 1995, z. 2: 123-128). Widać w niej wyraźny wpływ autorskiej koncepcji psychologicznej Witwickiego - kratyzmu, w której z kolei znać ślady twórczości Nietzschego. Por. Ryszard Jadczak, „Teoria kratyzmu Władysława Witwickiego", Acta Universitatis Nicolai Copernici 5, nr 121 (1981): 25-40. 


\section{Czy Sokrates był moralnym kastratem?}

W Zmierzchu bożyszcz Nietzsche wymienia jedną z najgorszych w jego ocenie zbrodni przeciwko życiu, pisząc: „Kościół zwalcza namiętność, trzebiąc w każdym tego słowa znaczeniu: jego praktyka, jego »kuracja« to kastrowanie. Nigdy nie pyta: »jak uduchowić, upiększyć, ubóstwić żądzę? « - w swej dyscyplinie zawsze kładł nacisk na tępienie [...] Ale zaatakować namiętności u samych ich korzeni, to zaatakować życie u samych jego korzeni” ${ }^{40}$. Oczywiście, zarzut ten nie dotyczy jedynie Kościoła, ale każdego kto przyjmuje podobną strategię. To problem bardziej uniwersalny, choć na podanym przykładzie najlepiej widoczny. To właśnie w duszach ludzi tego pokroju, którzy wiedzą, iż nie potrafią zapanować nad żądzami, rodzi się resentyment. W notatkach do wydanej pośmiertnie Woli mocy Nietzsche dodaje też: „Kastrat formułuje pewną sumę nowych warunków zachowania się dla ludzi zupełnie określonego gatunku"41. Ta bezradność wobec samych siebie rodzi bezradność wobec innych oraz chęć sprawienia, by ten kogo nie potrafię pokonać, komu nie umiem dotrzymać pola, stał się tak słaby jak ja. To zaprzeczenie ideału sokratejsko-nietzscheańskiego, gdzie pracę nad samoprzezwyciężeniem zastępuje się osłabianiem innych. Sauerland pisze o zaproponowanej przez Sokratesa „drodze rozumu” w następujący sposób: „Wedle Nietzschego Sokrates wiedział, iż to, co zaproponował, doprowadzi do śmierci. Jako uwodziciel potrafił również siebie samego przechytrzyć, słuchając tyrana, tzn. rozumu, i kończąc świadomie ze swoim życiem. Biorąc kielich śmierci, podał go także Atenom"42. Czy jednak faktycznie Sokratesowi można zarzucić taką resentymentalną postawę?

W końcowym akcie Gorgiasza, znaleźć możemy zaprzeczenie tym domysłom. Platoński Sokrates w zakończeniu przytoczonego mitu o zaświatach powiada: „Bo też, Kaliklesie, spośród potężnych jednostek wychodzą ci, którzy się wielkimi zbrodniarzami stają. A jednak nikt nie przeszkadza, żeby się i między tymi dobre jednostki trafiały, i mocno należy podziwiać tych, którzy się jednak tam zdarzają. Bo trudna to rzecz, Kaliklesie, i wielkiej godna pochwały, jeśli się

\footnotetext{
${ }^{40}$ Nietzsche, Zmierzch bożyszcz, 27.

${ }^{41}$ Tenże, Wola mocy, 144.

${ }^{42}$ Karol Sauerland, „Od Sokratesa do Zaratustry”, w: Nietzsche i tradycja antyczna, 130.
} 
posiadło wielką moc czynienia złego, sprawiedliwie życie przepędzić [pogrub. M.W.]"43.

Mistrz Platona uznaje zatem, że niektórzy ludzie większą moc posiadać mogą, a może nawet i powinni, lecz wiąże się ona $\mathrm{z}$ wielką odpowiedzialnością. Natomiast na największą chwałę zasłużyć powinien ten, kto ją posiadł, kto żądze i ambicje w sobie rozbudził, lecz w ich realizacji potrafi nałożyć sobie miarę.

Jak widzimy na wielu przykładach, Sokrates świetnie się bawi, uwodząc i będąc obiektem uwodzenia, czy to Teodoty ${ }^{44}$, czy to Alkibiadesa ${ }^{45}$, czy też Apollodorosa $^{46}$, Antystenesa ${ }^{47}$ lub wcześniej wspominanego Kritobulosa ${ }^{48}$. Nie brak więc w przekazach na jego temat świadectw, potwierdzających taką postawę. Pewne jest natomiast jedno, Sokrates namiętności nie unikał, ale panować nad nimi (zazwyczaj) potrafił. Potrafił je więc, jak pisał Nietzsche, „uduchowić, upiększyć, ubóstwić", zamiast trzebić życie u samych korzeni.

\section{Podsumowanie}

Rekapitulując dotychczasowe ustalenia, w pierwszej części artykułu zarysowany został kontekst oraz źródła konfliktu na linii Nietzsche-Sokrates, dotyczącego rozbieżności odnośnie do wartości uznawanej przez obu myślicieli za najwyższą. Ukazana tam opozycja pomiędzy instynktownością Nietzschego a racjonalnością Sokratesa została podważona w dalszej części tekstu.

W drugiej części zakwestionowana została dominująca pozycja racjonalizmu oraz intelektualizmu etycznego w aksjologicznej hierarchii Sokratesa. Przywołane świadectwa wyraźnie pokazują, że jego działalność ukierunkowana była nie tyle na zdobywanie wiedzy i kształtowanie formy cnoty, jaką był rozum, co raczej na rozbudzanie poznawczej niepewności, wybijającej rozmówców z „dogmatycznej drzemki”. Świadectwo Arystotelesa, który wyraźnie wskazuje, że twórcą teorii Idei

\footnotetext{
${ }^{43}$ Platon, „Gorgiasz”, 526a.

${ }^{44}$ Por. Ksenofont, „Wspomnienia o Sokratesie”, III, 11.

${ }^{45}$ Por. Platon, „Uczta”, w: Dialogi, t. I, tłum. Władysław Witwicki (Kęty: Antyk, 1999), 218c-219d.

${ }^{46}$ Por. Ksenofont, „Wspomnienia o Sokratesie”, III 11,16-17.

${ }^{47}$ Por. tenże, „Uczta”, 8,1-6.

${ }^{48}$ Por. tamże, $4,27-28$.
} 
był Platon, nie zaś jego mistrz, pozwala tym bardziej ukazać Sokratesa, jako myśliciela nieprzyjmującego dogmatycznie założonych samoistnych bytów idealnych, a co za tym idzie, odpowiadającej im najwyższej wiedzy i prawdy. W związku z tym pozycja, jaką w hierarchii wartości Sokratesa zajmuje racjonalizm, została znacząco osłabiona.

W trzeciej części artykułu, w której porównane zostały ze sobą postacie Nietzschego oraz Platońskiego Kaliklesa, ukazana została rola racjonalności, jako instancji regulującej i panującej nad - mającą zaspokajać ludzkie instynkty i żądze - wolą mocy. Warto zauważyć, że w swoich wczesnych wykładach przygotowanych jeszcze podczas pobytu w Bazylei, Nietzsche sam zdaje się postrzegać Sokratejski racjonalizm w podobny sposób ${ }^{49}$.

Ostatnia, czwarta część tekstu ukazała, że wartości uznawane za najwyższe, zarówno przez niemieckiego, jak i greckiego myśliciela, nie leżą wcale na przeciwległych krańcach aksjologicznej sceny, ale wychodząc z różnorodnych źródeł, spotykają się na wspólnym polu, które można by określić jako „instynkt racjonalności”. Jest to takie wykorzystanie potencjału naszej plastycznej natury, które uzgodni wolę mocy z rozumem. To stan, w którym - tak jak Sokrates - instynktownie, w pierwszej reakcji, słuchać będziemy nie tylko namiętności, ale również rozumu, który pozwala oceniać szanse i zagrożenia płynące ze spełnienia danej żądzy oraz w którym nasze reakcje instynktowne będą nie analitycznie, a właśnie odruchowo uzgadniane $z$ rozumem.

W związku z powyższym, większość zarzutów o myślenie i działanie „przeciwko” życiu i witalności, jakie Nietzsche stawia Sokratesowi, należy uznać za bezzasadne lub może raczej uzasadnione w przypadku przyjęcia bardzo konkretnego, subiektywnego obrazu Sokratesa, jaki wytworzył sobie autor Narodzin tragedi ${ }^{50}$. Zarówno Nietzsche, jak i Sokrates niejednokrotnie podkreślają, a potwierdza to

${ }^{49}$ Friedrich Wilhelm Nietzsche, The Pre-Platonic Philosophers, tłum. Gregory Whitlock (Chicago: University of Illinois Press, 2006), 145: „He is the first philosopher of life (Lebensphilosoph), and all schools deriving from him are first of all philosophies of life (Lebensphilosophien). A life ruled by thought! Thinking serves life, while among all previous philosophers life had served thought and knowledge: here the proper life appears as a purpose; there proper knowledge [is seen as] the highest".

${ }^{50} \mathrm{O}$ rozlicznych subiektywnych, nawet ze sobą sprzecznych obrazach Sokratesa w myśli Nietzschego por. James Porter, „Nietzsche and „The problem of Socrates”, w: A Companion to Socrates, red. Sara Ahbel-Rappe, Rachana Kamtekar (Oxford: Blackwell, 2006), 419, DOI: https://doi.org/10.1002/9780470996218.ch25 
i Kalikles, że życie oddane zupełnie we władanie namiętnościom, jest niewiele warte, bo nie posiadamy nad nim kontroli. Natomiast jedyną instancją wyższą, zdolną nad ich rozwiniętą formą zapanować, jest oceniający korzyści i zagrożenia z nich płynące rozum. Natomiast „dobre” i „autentyczne” życie to takie, w którym oba te elementy umiemy ze sobą uzgodnić.

\section{Bibliografia}

Arystoteles. Metafizyka. Tłum. Kazimierz Leśniak. Warszawa: Wydawnictwo Naukowe PWN, 1984.

Arystoteles. „O dowodach sofistycznych.” W: Arystoteles. Dzieła wszystkie. Tłum. Kazimierz Leśniak, t. I. Warszawa: Wydawnictwo Naukowe PWN, 1990.

Deleuze, Gilles. Nietzsche i filozofia. Tłum. Bogdan Banasiak. Warszawa: Wydawnictwo Spacja, 1993.

Fisher, Milena. „Nietzsche o moralności”. W: Nietzsche i tradycja antyczna, red. Bogdan Banasiak, Paweł Pieniążek, 221-231. Toruń: Wydawnictwo Adam Marszałek, 2012.

Guthrie, William Keith Chambers. Sokrates. Tłum. Krzysztof Łapiński, Sławomir Żuławski. Warszawa: Aletheia, 2000.

Hackforth, Reginald. „Great thinkers. (I) Socrates”. Philosophy 8, nr 31 (1933): 259-272. DOI: 10.1017/S0031819100032939.

Heidegger, Martin. Nietzsche. Tłum. Andrzej Gniazdowski, Piotr Graczyk, Wawrzyniec Rymkiewicz, Mateusz Werner, Cezary Wodziński, t. I. Warszawa: Wydawnictwo Naukowe PWN, 1998.

Hyland, Drew. „Nietzsche's »Love« for Socrates”. Humanities 2015, nr: 4: 3-16. DOI: $10.3390 / \mathrm{h} 4010003$.

Jadczak, Ryszard. „Teoria kratyzmu Władysława Witwickiego”. Acta Universitatis Nicolai Copernici 5, nr 121 (1981): 25-40.

Kaufman, Walter Arnold. „Nietzsche's admiration for Socrates”. Journal of the History of Ideas 9, nr 4 (1948): 472-491. DOI: 10.2307/2707219.

Kierkegaard, Soren Aabye. Okruchy filozoficzne. Tłum. Karol Toeplitz. Warszawa: Wydawnictwo Naukowe PWN, 1988.

Kierkegaard, Soren Aabye. O pojęciu ironii z nieustającym odniesieniem do Sokratesa. Thum. Alina Djakowska. Warszawa: Wydawnictwo KR, 1999.

Ksenofont. Pisma Sokratyczne. Tłum. Leon Joachimowicz. Warszawa: Wydawnictwo Naukowe PWN, 1967.

Kwiek, Marek. Rorty i Lyotard: w labiryntach postmoderny. Poznań: Wydawnictwo Naukowe Instytutu Filozofii UAM, 1994.

Legutko, Ryszard. Sokrates, filozofia męża sprawiedliwego. Poznań: Zysk i S-ka, 2013. 
Leoński, Jacek. „Historia wykorzystywania dokumentów osobistych w socjologii”. Ruch prawniczy, ekonomiczny i socjologiczny 1995, z. 2: 123-128.

Letkiewicz, Sławomir. Moralność dla wszystkich czy dla każdego? Katowice: Wydawnictwo Uniwersytetu Śląskiego, 2011.

Nietzsche, Friedrich Wilhelm. Antychrześcijanin. Tłum. Grzegorz Sowiński. Kraków: ZW Nomos, 1996.

Nietzsche, Friedrich Wilhelm. Narodziny tragedii albo Grecyi pesymizm. Tłum. Bogdan Baran. Kraków: Inter Esse, 1994.

Nietzsche, Friedrich Wilhelm. Tako rzecze Zaratustra. Tłum. Wacław Berent. Gdynia: Wydawnictwo Tenet, 1991.

Nietzsche, Friedrich Wilhelm. The Pre-Platonic Philosophers. Tłum. Gregory Whitlock. Chicago: University Of Illinois Press, 2006.

Nietzsche, Friedrich Wilhelm. Wola mocy. Tłum. Stefan Frycz, Konrad Drzewiecki. Kraków: Wydawnictwo Zielona Sowa, 2003.

Nietzsche, Friedrich Wilhelm. Zmierzch bożyszcz. Tłum. Paweł Pieniążek. Kraków: Wydawnictwo Zielona Sowa, 2006.

Olesiński, Dariusz. „Elenktyka jako therapeia w świetle Platońskiego Eutyfrona”. W: Therapeia, askesis, mediatio, red. Krzysztof Łapiński, Robert Pawlik, Rafał Tichy, 4960. Warszawa: Wydawnictwo UW, 2017.

Platon. Dialogi. Tłum. Władysław Witwicki, t. I i II. Kęty: Wydawnictwo Antyk, 1997.

Porter, James. „Nietzsche and »The problem of Socrates«”. W: A Companion to Socrates, red. Sara Ahbel-Rappe, Rachana Kamtekar, 406-425. Oxford: Blackwell, 2006. DOI: https://doi.org/10.1002/9780470996218.ch25.

Sauerland, Karol. „Od Sokratesa do Zaratustry”. W: Nietzsche i tradycja antyczna, red. Bogdan Banasiak, Paweł Pieniążek, 129-133. Toruń: Wydawnictwo Adam Marszałek, 2012.

Sikorski, Dariusz Konrad. „Sofistyka, nihilizm, totalitaryzm - myśli na XXI wiek”. Słupskie Prace Filologiczne. Seria Filologia Polska 2004, nr 3: 223-234.

Tymura, Dorota. Sokrates Ksenofonta. Lublin: Wydawnictwo UMCS, 2017.

\section{Summary}

Between instinct and rationality - the supreme value for Nietzsche and Socrates

Challenged in this paper is the general perception of how the concept of supreme value was perceived by Socrates and Friedrich Nietzsche. Socrates is usually described as an extreme rationalist while Nietzsche is referred to as a proponent of vitality and instinctive behaviour designed to increase the will to power. It follows from an analysis of Xenophon's and Plato's works by the author of this paper that the Athenian's ethical intellectualism was far from dogmatic. For his real goal was to raise his interlocutors' doubts in the discourse and stimulate 
critical thinking. This took often the form of a verbal agon, which actually corresponds with Nietzsche's will to power. Yet a juxtaposition of Callicles from Plato's Gorgias with Nietzsche's thought indicates that what mattered for them both apart from pure instinctiveness was the ability to control and overcome that phenomenon. The author concludes that neither Socrates nor Nietzsche should be associated with holding customarily extreme positions, and that the value considered by both as the supreme one was possessing an "instinct of rationality", that is taking such advantage of the potential of our plastic nature which reconciles the will to power with reason.

Keywords: Nietzsche, Socrates, supreme value, axiology, the will to power

\section{Zusammenfassung}

\section{Zwischen Instinkt und Rationalität - der höchste Wert für Nietzsche und Sokrates}

Das Ziel des Artikels ist die Polemik mit der gebräuchlichen Auffassung der Frage nach ein Anerkennung des höchsten Wertes bei Sokrates und Friedrich Nietzsche. Der eine wird als der extremer Rationalist dargestellt, dem anderen wird dagegen die Apotheose der Vitalität und des instinktiven Verhaltens zugeschrieben, das den Willen zur Macht stärken soll. Die im Artikel durchgeführte Analyse ausgewählter Motive aus den Schriften von Xenofon und Platon zeigt, dass die Gedanken des Atheners nicht einem dogmatischen ethischen Intellektualismus entspringen. Als seine wahren Ziele erweisen sich das Erwecken der Unsicherheit bei seinen Gesprächspartnern sowie der Vorsprung in der Diskussion, was häufig die Form von mündlichem Agon annahm, einer Entsprechung des Willens zur Macht bei Nietzsche. Die Zusammenstellung der Gestalt von Kalikles aus Platons Gorgias mit dem Gedanken Nietzsches verdeutlicht, dass ausser reinem instinktivem Verhalten auch die Fähigkeit seiner Beherrschung und Selbstüberwindung für sie zählte. Der Artikel gelangt zu der Schlussfolgerung, dass man weder Sokrates noch Nietzsche die gewöhnlichen extremen Haltungen zuschreiben sollte und dass für beide Philosophen als der höchste Wert der Besitz eines „Instinkts der Rationalität” galt - einer solchen Benutzung des Potenzials unserer plastischen Natur also, das den Willen zur Macht mit dem Verstand vereinbart.

Schlüsselworte: Nietzsche, Sokrates, der höchste Wert, Axiologie, der Wille zur Macht 
Information about Author:

MACIEJ WODZIŃSKI, philosophy student, Faculty of Philosophy and Sociology at the Maria Curie-Skłodowska University in Lublin; address for correspondence: Pl. Marii Curie-Skłodowskiej 4, PL 20-031 Lublin; e-mail address: maciek.wodzinski@gmail.com

\section{(cc) EY-NG-ND}

